\title{
SPECIALIZATION IN AGRITOURISM
}

\author{
ANNA JĘCZMYK, ${ }^{1}$ MARTINA HEDVIČÁKOVÂ ${ }^{2}$ \\ ${ }^{1}$ Poznań University of Live Sciences, POLAND \\ e-mail: ajeczmyk@up.poznan.pl \\ ${ }^{2}$ University of Hradec Králové, CZECH REPUBLIC \\ e-mail: martina.hedvicakova@uhk.cz
}

\author{
\begin{tabular}{l|l} 
RECEIVED & 5 May 2017
\end{tabular} \\ \begin{tabular}{l|l} 
ACCEPTED & 29 June 2017
\end{tabular} \\ JEL \\ CLASSIFICATION \\ Z32, L26 \\ KEYWORDS specialization, agritourism, agritourist farms, theme villages
}

ABSTRACT The aim of the article is to analyze the types of specialization of agritourism farms in Poland in the selected Polish literature and examples, which can lead to increased competitiveness. Agritourism itself signifies some kind of specialization. The choice of specialization made by the owners of agritourist farms depends on a variety of factors. The chosen specialty brings them specific benefits. It is also possible to observe specialization of villages, which is the basis of creating tourism products. At present, not only individual sites, but also whole villages are turning towards specialization. The specialization of whole villages, where apart from the offers of individual agritourist farms, tourists will receive something more - events of specific character, referring to the specialization theme.

The article has the character of a theoretical review and may encourage further research and scientific deliberations. It presents an analysis of agritourist farms specialization in Poland. The authors identifie specializations of these farms, which may become development stimulation factors. The method used in the work was literature and content analysis.

\section{Introduction}

Agritourism is not a new activity in rural areas, has been recognized around the world since the beginning of the 20th century (Gil Arroyo et al., 2013). It is a form of tourism which is rapidly developing in these areas. In Poland, this kind of activity is run by over 8,000 farms, offering 84,500 beds (Rolnictwo i obszary wiejskie, 2015). Currently, agritourism has become a broad concept, because apart from ordinary recreation, it comprises a range of other 
accompanying services, differentiating it from other forms of tourism. Agritourist farms are beginning to specialize, which allows the farmers to achieve satisfactory quality and enables them to use the potential of their farms and family members (Karbowiak, 2014).

The aim of the article is to analyze the types of specialization of agritourism farms in Poland in the selected Polish literature and examples. This process in agritourism is just beginning, but undertaking these actions shows that there is a change in the approach to the competitiveness of this form of tourism.

\section{Literature review}

In most definitions it is defined that agritourism must be held on the farm (Barbieri, Mshenga, 2008; Majewski, Lane, 2003; Sikora, 1999). Zelenka and Pásková (2012), Zelenka et al. (2014), Šimková et al. (2015) specify that activity allow effectively manage tourism development in order it is in line with natural resource limits their recovery time, while it is still beneficial to tourists, local community and the environment. Specialization is defined as the emergence of certain domains, a more precise division of work and functions, or as developing a skill, expertise in an individual field, or pursuing a particular line of work (Grądziel, 2014).

As regards the development of specialization on the international scale (trade between countries), traditional economic theories attach great importance to the existence of absolute and comparative advantages, as well as the benefits of synergy, which lead to sector concentration in individual countries (Ochojski, Polko, Churski, Kopczewska, 2016). The explanation of this phenomenon was based on the assumptions of the main theoretical trends in economics, including the classical, neoclassical, Keynesian and development economics, or the endogenous growth theory. With time the problems of specialization started to be considered and interpreted from the micro-economic angle of an individual company and its environment (Kopczewska, Churski, Ochojski, Polko, 2016).

Specialization is a process as a result of which an enterprise, region or country focuses on certain goods and at the same time ceases to produce other commodities; it is also understood as a result of such a process (Bremond, Couet, Salort, 2005). Narrow specialization, as well as the quality of service, stable relations with clients and the innovative character of products or services, increases the chances of winning competition (Skalik, 2005). The growing competition among economic entities functioning on the market has generated the need for specialization of offers.

Specialization is also perceived on the agritourist services market as an effect of the rapid development of this activity in rural areas. Despite the fact that Polish countryside with its landscape, rituals and customs is a product in itself; organizers of recreation in the country look for assets of the natural and cultural environment which will make their offer exceptional, unique and thus - more attractive to tourists (Jęczmyk, Maćkowiak, Uglis, 2014).

Agritourism development in Poland has become an inherent element of the growth of rural areas. This form of tourism adjusts to the tourists' needs, and satisfying them makes it possible to gain an additional source of income and the upper hand in the competition with those farms which do not offer other services except accommodation and board. Specialization allows farmers to use the potential of their farm and family members, as well as achieve a satisfactory quality level. Facing the large supply of agritourist farms, they must offer something special to win their own clients. These activities will include not only raising the standard of accommodation, but first of all searching for attractions which could be offered to an agritourist by the farm itself or its vicinity (Jęczmyk, Bogusz, 2017). 
Žlábková (2017) deals with the quality of life in rural areas and diversification of the rural economy. She describes the socio-economic situation in the Czech Republic are evaluated indicators measure of support to tourism.

Due to agritourist activity specialization, owners of agritourist farms are able to (Srebro, Majewski, Mikołajewicz, 2009):

- more effectively match their offer to the expectations of specific categories of clients, thus the tourist is more satisfied with their stay at the farm, which enhances the image of the whole offer,

- reach clients through specialist communication channels more easily,

- run more effective and less costly marketing by creating specially prepared packages for specific target groups,

- make their offer more competitive than the general offer,

- make a more extended offer automatically more expensive.

The main purpose of agritourist farm specialization is to increase the number of clients or/and their expenditure. Therefore, it should begin as early as the stage of creating the product, which involves providing high quality services as regards accommodation, board, tourist attractions, suitable infrastructure and service. The product on offer should guarantee high standard, as well as meet the client's expectations and needs.

Those interested in specialist products expect offers with distinctive, specific features. Specialization improves the competitiveness of the farm on the market, and helps to prolong the tourist season (Kmita-Dziasek, 2011).

\section{Method}

The article has the character of a theoretical review and may encourage further research and scientific deliberations. It presents an analysis of agritourist farms specialization in Poland in the selected Polish literature. The authors identifie specializations of these farms, which may become development stimulation factors.

The method used in the work was literature analysis and content analysis. The authors reviewed the available publications concerning specialization and its role in running an agritourism business, as well as analysed online agritourist offers.

\section{Results}

The issue of agritourist farm specialization, which may develop in different directions, has been discussed by various authors.

Agritourism itself signifies some kind of specialization (Majewski, 2001). Its particular features make it different from other types of tourism in rural areas:

- it is limited to agricultural areas,

- it is strictly connected with a farm (animal, fish or horticultural one),

- it uses villagers' residential and farm buildings for accommodation purposes,

- it is characterized by active recreation in the natural environment of the farm.

This form of tourism is immanently connected with the farm and the rural area. Agritourism involves resting in a farmer's house, on an active farm, where it is possible not only to sleep, eat meals prepared from local products, take part in field and farm work, observe animal breeding and plant growing (which is a major attraction), but also do recreational activities on and outside the farm (Jęczmyk, Uglis, 2014). 
Jalinik (2007) proposed a typology of agritourist farms, where he presents different types according to their specificity and approach to the client, paying attention to the relationship between the quality of services, price level, the tourist attractiveness and quality of the natural environment and the demand for tourist services. He identifies seven types of agritourist farms, including four general and three specialist ones. The general types include (Jalinik, 2009a):

- type $U$ - universal, i.e. adjusted to the needs of many tourists,

- type $\mathrm{C}$ - for families with young children,

- type D - an offer for disabled people, especially those with mobility impairment,

- type E - an offer for the elderly.

The specialized farms include the following (Jalinik, 2009b):

- type I sr - with developed sports and recreational infrastructure,

- type II Ih - with good living and housing conditions,

- type III sp - specialist farms, organizing handicraft, horse riding, apitherapy, phytotherapy and other workshops.

Smoleńska and Machnik (2013) analyse agritourist farms specialization with reference to individual and group tourism (Table 1), attracting different types of tourists.

Table 1. Tourists staying on agritourist farms

\begin{tabular}{ll}
\hline & - independent youth and students (15-25) \\
& - young independent adults, with no family (25-45) \\
Individual tourism & - families with children aged $6-15$ \\
& - adults up to 60 years of age \\
& - elderly people $(60-75$ years of age) \\
\hline \multirow{3}{*}{ Group tourism } & - educational groups, mainly children and youth \\
& - hobby groups with special interests \\
& - young people's organizations and sport associations \\
\hline
\end{tabular}

Source: Smoleńska, Machnik (2013), p. 134.

A kind of specialization is categorization in agritourism, which plays a very important role in raising service quality. It is voluntary, implemented by the Polish Federation of Rural Tourism - "Hospitable Farms". A farm may be given one out of three ranks (1,2 or 3 "little suns") in two categories: "Recreation in the country" and "Recreation at a farmer's place". However, in order to be specialized in the "Recreation at a farmer's place" category, the farmstead must meet additional criteria, specific of the agricultural farm. The "Hospitable Farms" website recommends 1,257 categorized facilities (http://www.agroturystyka.pl, 4.03.2017).

The same website presents special offers (http://www.agroturystyka.pl, 4.03.2017):

- a rural tourism hit: an offer including 33 tourism products which are to be associated with high standard and quality of service, as well as an interesting, extremely varied tourist offer,

- at a farmer's house: 33 facilities,

- for a mushroom picker: 16 facilities,

- a room in an eco-farmer's house: 76 facilities,

- for a fisher: 10 facilities,

- horse riding: 8 facilities,

- for families with children: 24 facilities. 
The proposed domains of specialization are a symptom of the changing approach to the competitiveness of the rural accommodation infrastructure. It is not only the sale of agritourist services anymore (mostly accommodation services), but the sale of a full specialist tourist product.

An example of using specialization in agritourism are educational farms, which are also a very good example of innovative entrepreneurship in rural areas. The essence of educational farms lies in familiarizing the society with the natural environment of a farm in the countryside, conveying knowledge about the origins of food, the effort put into producing it and the significance of agriculture, in order to create a growing group of conscious clients on the market (Bogusz, Kmita-Dziasek, 2015). The Polish Network of Educational Farms website presents 223 educational farms (http://www.zagroda-edukacyjna.pl, 4.03.2017).

We may also observe specialization of whole villages, where apart from the offers of individual agritourist farms, tourists will receive something more - events of specific character, referring to the specialization theme.

A theme village differs from other forms of countryside specialization in that its specialization fits an economy based on knowledge, experience and creativity, as well as is created on the basis of new development factors, usually non-material and emotional (Idziak, 2008). The theme should be based on the local material and nonmaterial resources (e.g. cultural and natural heritage), as well as be complementary to the local specificity (e.g. the inhabitants' passions and skills) (Idziak, Idziak, Kamiński, 2015).

The result of theme specialization is the appearance of theme parks, museums, exhibitions, restaurants, shops, as well as cities or their districts, villages and farms. In Poland, there are 63 theme villages (Kłoczko-Gajewska, 2015), most popularly (15) found in the Warmia - Mazury Province. Examples of theme villages in Poland are: Sierakowo Sławieńskie - Hobbits' Village, Krzywogoniec - Mushroom Villages, or Stare Jabłonki -the Village of Apple Tastes.

\section{Conclusions}

The analysis above shows that agritourist farms can specialize based on different factors. They may be special offers for specific tourist groups, or offers of specific infrastructure and recreation facilities, which might satisfy tourists' needs. At present, not only individual sites, but also whole villages are turning towards specialization.

Specialization is not a common feature of Polish agritourism, though there are products which may be described as special. This trend matches tourists' expectations.

Authors in this article represent the approaches to classification of agrotourism farms, which are available in the Polish literature, but this topic need wider literature studies and research among owners of agritourism farms.

\section{References}

Barbieri, C., Mshenga, P.M. (2008). The role of the firm and owner characteristics on the performance of agritourism farms. Sociologia Ruralis, 48, 166-183.

Bogusz, M., Kmita-Dziasek, E. (2015). Zagrody edukacyjne jako przykład innowacyjnej przedsiębiorczości na obszarach wiejskich. In: W. Kamińska (ed.), Innowacyjność w turystyce wiejskiej a nowe możliwości zatrudnienia na obszarach wiejskich (pp. 155166). Warszawa: Komitet Przestrzennego Zagospodarowania Kraju PAN, Tom CLXIII.

Bremond, J., Couet, J.F., Salort, M.M. (2005). Kompendium wiedzy o ekonomii. Warszawa: Wydawnictwo Naukowe PWN.

Gil Arroyo, C., Barbieri, C., Rich, S. (2013). Defining agritourism: A comparative study of stakeholders' perceptions in Missouri and North Carolina. Tourism Management, 37, 39-47.

Grądziel, A. (2014). Strategia inteligentnej specjalizacji stymulatorem rozwoju gospodarczego regionów. Studia i Prace Wydziału Nauk Ekonomicznych i Zarządzania, Gospodarka regionalna i międzynarodowa, 2 (37), 243-253. 
Idziak, W. (2008). Wymyślić wieś od nowa. Wioski tematyczne. Koszalin: Alta Press.

Idziak, W., Idziak, P., Kamiński, R. (2015). Ekspertyza „Wsparcie dla rozwoju turystyki wiejskiej i agroturystyki w ramach Programu Rozwoju Obszarów Wiejskich na lata 2014-2020 oraz z krajowych i regionalnych programów operacyjnych". Warszawa: Ministerstwo Rolnictwa i Rozwoju Wsi.

Jalinik, M. (2007). Typologia gospodarstw agroturystycznych. Roczniki Naukowe SERiA, 2 (IX), 109-116.

Jalinik, M. (2009a). Uwarunkowania i czynniki rozwoju usług turystycznych na obszarach wiejskich. Rozprawy Naukowe 173, Białystok: Wydawnictwo Politechniki Białostockiej.

Jalinik, M. (2009b). Propozycje zmian w kategoryzacji gospodarstw agroturystycznych. Wieś i Rolnictwo, 3 (144), 109-122.

Jęczmyk, A., Bogusz, M. (2017). Educational farms as an example of the Polish agritourism farms specialization (pp. 356-362). International Scientific Conference Hradec Economic Days. Vol. 7. Hradec Kralove: University of Hradec Kralove.

Jęczmyk, A., Maćkowiak, M., Uglis, J. (2014). Dziedzictwo kulinarne elementem przewagi rynkowej w ofercie gospodarstw agroturystycznych. Roczniki Naukowe Stowarzyszenia Ekonomistów Rolnictwa i Agrobiznesu, 2 (XVI), 103-108.

Jęczmyk, A., Uglis, J. (2014). Organizacyjno-prawne uwarunkowania rozwoju turystyki na obszarach wiejskich. In: K. Zarzecka, S. Kondracki (eds.), Współczesne Dylematy Polskiego Rolnictwa, cz. I (pp. 283-292). Biała Podlaska: Wydawnictwo PSW JPII.

Karbowiak, K. (2014). Rozwój agroturystyki w Polsce w latach 2010-2013. Zagadnienia Doradztwa Rolniczego, 4, 34-44.

Kłoczko-Gajewska, A. (2015). Działalność wiosek tematycznych w Polsce i wstępna ocena jej efektów. Roczniki Naukowe Ekonomii Rolnictwa i Rozwoju Obszarów Wiejskich, 3 (102), 104-111.

Kmita-Dziasek, E. (2011). Wprowadzenie do zagadnień edukacji w gospodarstwie rolnym. Kraków: Centrum Doradztwa Rolniczego w Brwinowie Oddział w Krakowie.

Kopczewska, K., Churski, P., Ochojski, A., Polko, A. (2016). Specjalizacja regionalna - systematyzacja pojęć i metod pomiaru. In: A. Klasik, F. Kuźnik (eds.), Specjalizacja regionalna - współczesne podejścia (pp. 8-25). Warszawa: Studia KPZK PAN.

Majewski, J. (2001). Specjalistyczne produkty w agroturystyce. In: J. Majewski (ed.) Specjalizacja w agroturystyce (pp. 32-43). Poznań: AR and MTP.

Majewski, J., Lane, B. (2003). Turystyka wiejska i rozwój lokalny. Warszawa: Fundacja Fundusz Współpracy.

Ochojski, A., Polko, A., Churski, P., Kopczewska, K. (2016). Specjalizacja regionalna: podstawy koncepcyjne i aspekty integracyjne. In: A. Klasik, F. Kuźnik (eds.), Specjalizacja regionalna - współczesne podejścia (pp. 26-44). Warszawa: Studia KPZK PAN.

Rolnictwo i obszary wiejskie w latach 2007-2015 (2015). Warszawa: Ministerstwo Wsi i Rolnictwa.

Sikora, J. (1999). Organizacja ruchu turystycznego na wsi. Warszawa: WSiP.

Skalik, J. (2005). Rynkowe i pozarynkowe uwarunkowania wzrostu konkurencyjności małych i średnich przedsiębiorstw. In: R. Krupski (ed.), Zarządzanie Strategiczne. Strategie małych firm (pp. 153-161). Wałbrzych: Poddruk.

Smoleńska, O., Machnik, A. (2013). Współczesne uwarunkowania funkcjonowania turystyki wiejskiej - rozwój gospodarstw agroturystycznych w kierunku specjalizacji w rekreacji i ekologizacji oferty. Zeszyty Naukowe, Studia Periegetica, 2 (10), 127-138.

Srebro, B., Majewski, J., Mikołajewicz, A. (2009). Materiały szkoleniowe. Standardy jakości w agroturystyce. Nowy Sącz: Sądecka Organizacja Turystyczna.

Šimková, E., Jackmann, J., Holzner, J. (2015). Management approaches towards entrepreneurship in rural tourism. International Conference Hradec Economic Days 2015 Economic Development and Management of Regions. Vol. 5. Hradec Králové: Gaudeamus.

Zelenka, J., Pásková, M. (2012). Cestovní ruch - výkladový slovník. Praha: Linde.

Zelenka, J., Štekerová, K., Paskova, M., Prochazka, J. (2014). Aplikace umělé inteligence a kognitivní vědy v udržitelnosti cestovního ruchu. Hradec Králové: Gaudeamus.

Žlábková, J. (2017). Support for rural tourism (pp. 984-991). International Scientific Conference Hradec Economic Days. Vol. 7. Hradec Kralove: University of Hradec Kralove.

Cite this article aS:" Jęczmyk, A., Hedvičáková, M. (2017). Specialization in agritourism. European Journal of Service Management, 3 (23), 39-44. DOI: 10.18276/ejsm.2017.23-05. 